\title{
CB Research S Suare \\ New Records of Neobenedenia Girellae (Hargis, 1955) \\ (Monogenea: Capsalidae) In Marine Ornamental Fish Imported To Yucatan, Mexico
}

Amelia Paredes-Trujillo ( $\square$ amelia.paredes@unach.mx )

Universidad Autónoma de Campeche https://orcid.org/0000-0003-2182-5987

Victor Manuel Vidal-Martínez

Centro de Investigación y de Estudios Avanzados del Instituto Politécnico Nacional

David Hernández

Centro de Investigación y de Estudios Avanzados del Instituto Politécnico Nacional

David Gonzalez-Solis

El Colegio de la Frontera Sur

Rodolfo del Río-Rodríguez

Universidad Autónoma de Campeche

\section{Research Article}

Keywords: Neobenedenia girellae, monogenean, capsalidae, marine ornamental fish.

Posted Date: December 17th, 2021

DOI: https://doi.org/10.21203/rs.3.rs-1135493/v1

License: (c) (i) This work is licensed under a Creative Commons Attribution 4.0 International License. Read Full License 


\section{Abstract}

We detected $N$. girellae infections in 40 species belonging to 12 families of imported marine ornamental fish from a public aquarium in the Mexican state of Yucatan in January 2018 to December 2020 and carried out their identification to the species level using morphological and molecular analyses. Monogeneans were corroborated morphologically and molecularly using a partial sequence of 28S (region D1-D3) ribosomal DNA and analyzed in a molecular phylogenetic context in combination with data derived from other species of $N$. girellae available in GenBank. The phylogenetic tree revealed that the specimen found consistently belonged to the $N$. girellae clade. High infection parameters were detected of $N$. girellae in the hosts. This identification is relevant to aquarists and aquaculturists in the Gulf of Mexico because $N$. girellae is considered highly pathogenic in confined fish. Clearly, this work demonstrates that the importation of ornamental fish, coupled with deficient sanitary measures (lack of quarantine areas in distribution centres) contributes to the introduction of parasites and their establishment and dispersal within Mexico.

\section{Introduction}

Capsalid monogeneans comprise approximately nine subfamilies, 57 genera and over 300 species, infecting predominantly the skin and gills of marine fish (Whittington 1994; Ogawa et al. 1995; Gibson et al. 2010). Some genera are well-known, e.g. Benedenia Diesing, 1858, Capsala Bosc, 1811, Entobdella Blainville in Lamarck, 1818, Neobenedenia Yamaguti 1963 are considered highly pathogenic and responsible for severe outbreaks of epizootics, causing severe economic losses with regard to farmed and aquarium fish (Gaida and Frost 1991; Whittington 1994). Shinn et al. (2015) reported economic losses due to Neobenedenia melleni (MacCallum, 1927) Yamaguti, 1963 infections in cobia in Taiwan, with mortality of $40 \%$ and a loss of 1.80 million USD. In Japan and Australia, Benedenia seriolae (Yamaguti, 1934) Meserve, 1938 affected Japanese amberjack (Seriola quinqueradiata) and Greater amberjack (Seriola dumerili), with losses of up to 214 and 0.53 million USD, respectively. In particular, Neobenedenia has been reported to infect a bewilderingly large number of fish including more than 100 fish species and about 30 families (Whittington and Horton 1996; Whittington 2004; Whittington and Chong 2007; Sepúlveda and González 2019; Magalhães-Cardoso et al. 2019). Outbreaks of Neobenedenia ssp. have been widely detected in commercial species from Asia, (Epinephelus coioides, Lutjanus argentimaculatus, L. johnnii, Pinjalo pinjalo, Seriola dumerili, S. quinqueradiata, S. rivoliana) (Seng 1997; Hirayama et al. 2009; Ohno et al. 2009; Hirazaga et al. 2016a, b; Sicuro and Luzzana 2016); the Northwest Pacific (Paralichthys olivaceus and Verasper variegatus) (Seng 1997; Hutson 2007); Indonesia, Australia (Barramundi Lates calcarifer) (Seng 1997) and Mexico (Seriola lalandi) (Avilés-Quevedo and Castelló-Orvay 2004) as well as in several ornamental marine fish from Brazil (Chaetodon semilarvatus, Pomacanthus asfur, P. maculosus, Pygoplites diacanthus) (Magalhães-Cardoso et al. 2019); Mexico (Canthigaster bennetti); Australia (Nemateleotris decora, Neocirrhites armatus, Pseudocheilinus hexataenia, Pseudochromis fridmani), Africa (Gnathanodon speciosus) (Brazenor et al. 2018a). Specifically, Neobenedenia girellae (Hargis 1955) Yamaguti, 1963 is a lethal and persistent species, with a wide geographic distribution and a high infective capacity in several hosts (Hiramaya et al. 2009; Brazenor et al. 2018a, b; Tedesco et al. 2021). It has been recorded in approximately 30 host species, including several tropical reef fish families Carangidae, Cirrhitidae, Coryphaenidae, Labridae, Latidae, Microdesmidae, Pleuronectidae, Pseudochromidae, Rachycentridae, Serranidae (Brazenor et al. 2018 a, b) among others. Due to its short life cycle and low host specificity, it can become highly prevalent and cause large numbers of mortalities of aquarium fish (Nam et al. 2020). The elevated abundance of $N$. girellae causes considerable irritation to fish, e.g., weakness, anorexia, dyspnea, mild haemorrhages on the skin and eyes, mucus hypersecretion, blindness and death due to secondary infections (mainly bacterial infections) if not treated (Hirazaga et al. 2016a, b). This parasite was described in Girella nigricans for the first time in California, United States (Hargis 1995). Subsequently, it was described in several localities in Mexico (among other regions of the world) (Bravo-Hollis and Deloya 1973; Moser and Haldorson 1982; Gaida and Frost 1991; Ogawa et al. 2006), including in Mycteroperca pardalis and Scarus perrico in La Paz Baja California and Nayarit, respectively (Bravo-Holis 1958). The export and import of fish for aquaculture is likely one of the most important sources of its dispersion (Salgado and Rubio 2014). However, the role of the ornamental fish trade in the translocation and establishment of wild and farmed fish has received limited attention in Mexico. The present research thus focused on the detection and identification of $N$. girellae in traded marine ornamental fish into the state of Yucatan.

\section{Materials And Methods}


The marine ornamental fish examined in this study were donated by a commercial aquarium in Merida, Yucatán between January 2018 to December 2020, a total sample of 348 ornamental fish (Table 1). Most of the fish were originally captured from the natural environment of the Indo-Pacific region, although the exact capture locations were not available to the importer. The ornamental fish were imported from their centre of origin and distributed to several regions of Mexico (specifically, until their point of sale) or transferred to the market Morelos in Mexico City, which represents one of the main commercialization and distribution centres for ornamental fish, before being dispersed throughout the country (e.g. Merida, Yucatán). The imported fish were transported in isolated plastic bags with artificial aeration. Once at their point of sale (i.e. the aquarium in Merida), the dead or dying fish were separated and kept in coolers, posteriorly donated and transported to the Aquatic Pathology Laboratory at CINVESTAV-IPN Unidad Mérida for parasitological examination. Once at the laboratory, fish was measured to obtain its total length (TL, cm), standard length $(\mathrm{SL}, \mathrm{cm})$ and total weight $(\mathrm{W}, \mathrm{g})$. The surface of the skin and eyes, gills, scales from the lateral line and fins were examined under a stereomicroscope (Stemi 305 Carl Zeiss) for ectoparasites. Whenever parasites were found, they were counted, preliminarily identified to the genus level and fixed depending on the taxonomic group (Whittington 2004). Capsalid monogeneans were isolated, counted in situ, cleaned with physiological saline and preserved in $4 \%$ formalin or $96 \%$ alcohol labelled vials for subsequent morphological or molecular studies, respectively (Brazenor et al. 2018a, b). They were removed with fine paintbrushes, stained with ammonium picrate and identified to the species level according to suitable literature (e.g., Whittington and Kearn 1993; Hargis 1995; Ogawa et al. 2006). Infection parameters, such as prevalence, mean abundance and mean intensity were those proposed by Bush et al. (1997). Standard measurements were made using an OLYMPUS BX50 compound microscope (Olympus, Tokyo, Japan) and ImageJ software (Wayne Rasband Scientific Software, Kensington, Maryland, USA). Drawings were prepared using Adobe Illustrator software (Adobe Inc., San Jose, California, USA). The following features were measured for morphological and morphometric description: body length and width; pair of anterior attachment organs, length by width; haptor, length; anterior hamuli, length, posterior hamuli, length, accessory sclerites, length; pair of testes, length by width; ovary, length by width; egg, length by width (Whittington and Kearn 1993; Whittington 2004) (Table 2). All measurements are given below in millimetres (mm), with the range followed by the mean in parentheses (Table 2).

\section{Dna Amplification, Sequencing And Phylogenetic Analyses}

For the genetic study, genomic DNA was extracted from each specimen of Neobenedenia using a DNeasy TM Blood \& Tissue Kit (Qiagen, Hilden, Germany) following the standard manufacturer's protocol. Specimens of different host species were chosen for extraction. Given that the 28S ribosomal gene has been used in other studies to identify species of Neobenedenia (Brazenor et al. 2018a, b), we also amplified the D1, D2 and D3 regions of this gene. The amplification was carried out with the primers 391 (Nadler and Hudspeth 1998) and 536 (García-Varela and Nadler 2005), and the conditions of the polymerase chain reaction (PCR) amplification were: $94^{\circ} \mathrm{C}$ for $5 \mathrm{~min}, 35 \mathrm{cycles}$ at $94^{\circ} \mathrm{C}$ for $1 \mathrm{~min}, 50^{\circ} \mathrm{C}$ for $1 \mathrm{~min}, 72^{\circ} \mathrm{C}$ for $1 \mathrm{~min}$ and a post-amplification extension at $72^{\circ} \mathrm{C}$ for $10 \mathrm{~min}$. For sequencing, the two amplification primers plus 503 (Stock et al. 2001) and 504 (García-Varela and Nadler 2005) were used. Sequencing was carried out in GENEWIZ (South Plainfield, NJ, USA). The sequences obtained from each primer were read, edited and assembled into a consensus sequence for each extracted specimen using Geneious Pro 4.8.4® (Biomatters Ltd.). The new sequences were submitted to GenBank for publication and public access. For phylogenetic analyses, the new sequences were aligned with other $28 \mathrm{~S}$ sequences from Neobenedenia available in GenBank. The alignment was performed using ClustalW (Thompson and Gibson 1994), implemented in http://www.genome.jp/tools/clustalw/ ("SLOW/ACCURATE" and "CLUSTALW (for DNA)"). The nucleotide evolution model was estimated in jModelTest v.2 (Darriba et al. 2012). A maximum likelihood analysis (ML) was performed to obtain the phylogenetic tree with RAxML v. 7.0.4 (Stamatakis 2006) and 1,000 bootstrap repetitions (bt) were implemented. The ML tree was visualized in FigTree v.1.4.3. (Rambaut 2000). The genetic distances of $28 \mathrm{~S}$ gene, were calculated using uncorrected $p$-value (p-distances) in MEGA v.6.0 (Tamura et al. 2013).

\section{Results}

A total of 348 fish specimens of 40 species belonging to 12 families were examined for monogeneans (Table 1). A total of 213 fish were infected, and $803 \mathrm{~N}$. girellae were collected, identified, infecting the skin, the surface of the eyes and/or the gills of host species of all the families mentioned (Table 1; Fig. 1). Macroscopic external lesions were observed in parasitized fish epidermal damage associated with the site of haptor attachment, mild haemorrhages on the skin and eyes, exophthalmia, presence of dyspnea and anorexia. The morphological characteristics of collected parasites matched those of the genus Neobenedenia

Page $3 / 10$ 
described by Whittington and Kearn $(1993,2004)$ as morphologically flattened, leaf-like body shape, absence of haptoral septa and a vagina, although having accessory sclerites, haptoral hamuli, paired anterior circular discs and 2 juxtaposed testes, which is a unique combination to this genus (Table 2). Monogeneans were collected from all the families, therefore representing new host records. Prevalence ranged $8-100 \%$ in the hosts, with mean abundance and intensity ranging $0.13 \pm 2.05$ to $32 \pm 27.78$ and $32 \pm 27.78$ to $48 \pm 42.85$, respectively (Table 1). The morphological measurements of the host species are presented in Table 2.

\section{Phylogenetic analyses}

Six new sequences were successfully obtained from parasites that came from six different host species, with a length of 1,123 to 1,203 base pairs (bp). The length of the final alignment was $1,249 \mathrm{bp}$. The estimated substitution model was GTR + GAMMA and the nucleotide frequencies were 0.259 (A), 0.178 (C), and 0.300 (T). The maximum likelihood (ML) had a value of - s3209.140011. The phylogenetic tree showed a major clade with a high support value $(\mathrm{bt}=86)$, where $N$. girellae was grouped with two other species of the genus, which were only recognized as Neobenedenia sp (Fig. 2). In particular, within the clade of N. girellae (bt=73), most of the specimens identified for this species were grouped, including the specimens of our study. The exception was the specimen MH843692, which despite being named as $N$. girellae, was grouped in a different independent clade of the tree. The genetic distance was null among the specimens collected in this study. The intraspecific genetic distance of the clade $N$. girellae ranged from 0 to $0.9 \%$. The distance between the specimens of the clade $N$. girellae and the specimen that was grouped in a different independent clade ranged from 6.8 to $7.2 \%$. Finally, the genetic distance between $N$. girellae and the other species of the genus represented in our phylogenetic analysis ranged from 1.1 to $11.2 \%$.

\section{Discussion}

Presented here are the first confirmed molecular and morphological data of $N$. girellae in Yucatán, Mexico. This monogenean represents new host records and shows the wide range of aquarium fish that this parasite can infect (see Table 1). We consider our findings relevant for aquaculturists and pet shop owners in the Gulf of Mexico, because $N$. girellae is an emerging parasitic infection and a potential threat to the trade of ornamental fish. Although this monogenean species is well-established in Mexico, our findings indicate that there is a constant reintroduction of the parasite in different regions, possibly following market routes. We suggest that the parasite has at least two possible origins, although neither is conclusive. Through the movement of imported infected fish and the possibility of acquiring infections within reservoir centres (Morelos markets), the fish are kept in confinement without adequate sanitary measures, before being distributed to various regions of Mexico. Clearly, the importation of ornamental fish is one way that contributes to the introduction of parasites and their dispersal and establishment within Mexico. The international trade of ornamental fish has been identified as a threat to transboundary biosecurity, biodiversity and future aquaculture development (Whittington and Chong 2007; Salgado-Rubio 2014; Mendoza and Aguilera 2015). The stress associated with the capture, handling and transport of ornamental fish from their origin, coupled with deficient sanitary measures (lack of quarantine areas in distribution centres) and mishandling, facilitates these parasites' dispersal. Elevated infection rates are commonly observed in aquarium fish owing to high stocking density and sometimes inadequate water quality maintenance (Magalhães-Cardoso 2019). During transport, the fish are handled in excess, being placed in overcrowded plastic bags with low oxygen levels and increasing amounts of nitrogenous waste due to excretion (ammonium). These deteriorating conditions pave the way for the establishment of this monogenean. The presence of $N$. girellae has been reported in various ornamental marine species, e.g. Chaetodon, Nemateleotris decora, Neocirrhites armatus, Pseudocheilinus hexataenia, Pseudochromis fridmani, Pomacanthus asfur, P. maculosus, Pygoplites diacanthus, Trachinotus blochii in Brazil, Australia and Korea; however few studies have reported on infection parameters (Gaida and Frost 1991; Ogawa et al. 1995; Ogawa et al. 2006; Hirayama et al. 2009; Hirazaga et al. 2016a; Brazenor et al. 2018a, b; Nam et al. 2020). In this study, high prevalences were found in the most the host. Putri et al. (2020) reported a prevalence of $60 \%$ of $N$. girellae in Rachycentron canadum from Indonesia, while Gaida et al. (1991) reported a prevalence of $75 \%$ in Medialuna californiensis from California. The life cycle of $N$. girellae is short, a smaller body size being needed to attain maturity. Bondad-Reantaso et al. (1995) identified the rapid development of $N$. girellae in Japanese flounder, reaching sexual maturity in $10-11$ days at $25^{\circ} \mathrm{C}$ from oncomiracidia. There were $15-17$ days from egg to maturation. In the present study, this parasite was particularly abundant on the eyes, causing corneal opacity and skin irritation.

Neobenedeniagirellae harm fish via mechanical attachment by the haptor; Ogawa et al. (2006) found particular histological damage in the cornea of infected fish displaying hyperplasia of squamous epithelial cells and mucous cells. Hirazawa et al. (2016) reported lower haematological parameter values, haematocrit, blood urea nitrogen and total protein and globulin in fish

Page $4 / 10$ 
severely infected with $N$. girellae. On the other hand, $N$. girellae is an ectoparasite that is well-adapted to tropical regions, so it can be foreseen successful establishment in wild native fauna and cultured fish in Yucatán in case they reach the open environments. Brazenor et al. $(2018 \mathrm{a}, \mathrm{b})$ found that this parasite completed its life cycle almost twice as quickly in warm, high-saline conditions compared to cooler temperatures, i.e. oncomiracidia's longevity is significantly lower in salinities below $22 \%$ compared to in higher saline conditions (35-40\%). Moreover, at $20-25^{\circ} \mathrm{C}$, the parasite attained sexual maturity and produced eggs more slowly than at $30{ }^{\circ} \mathrm{C}$. In this sense, the Yucatán marine environment provides suitable habitats for this parasite's establishment and reproduction, given its high temperatures, high salinity and multiple reef spots. Unfortunately, in Mexico no regulations exist for the importation and introduction of ornamental species to the market, allowing practically any aquatic organism of this sort to be introduced with limited sanitary control (Contreras and Carrillo 1998; Cedillo et al. 2001). A health certificate declaring that imported fish into Mexico are free from World Organisation for Animal Health (OIE) listed diseases is compulsory, otherwise the entry of such goods is denied. Although $N$. girellae is a dangerous pathogen, it is not currently included on the list of diseases. Furthermore, even though health authorities conduct physical inspections at some border points, marine ornamentals, as a valuable commodity, must be transferred swiftly; therefore, fish carrying parasites or disease are practically unnoticed. We consider it equally important that sanitary agents be trained to recognize significant pathogens besides the listed diseases that can be problematic for aquaculture and the aquarium industry. Containment measures such as quarantine may be worth reviewing in terms of their effectiveness in preventing parasite detection, with the aim of reducing the spread of disease.

\section{Conclusion}

Neobenedenia girellae was detected in a total of 40 imported species of marine ornamental fish belonging to 12 families. High prevalences were found in the most the host. Six new sequences were successfully obtained from parasites originating in six different host species, amplified and sequenced to produce 28S. A BLAST search gave the highest identity with $N$. girellae from several host species. These results emphasize the effect of the lack of quarantining of aquatic fish captured from nature, before being stored for commercialization, given our knowledge of pathogens and emerging diseases in Mexico. We believe that it is necessary to strengthen sanitary and control points to reduce the introduction of pathogens, e.g. by: defining the risk of introducing imported ornamental fish in order to protect the country's wild species from invasive diseases; identifying existing pathogens and emerging diseases; improving the surveillance of fish pathogens; linking information on imported ornamental fish that have become established in the wild with data on pathogens that have been detected; and reviewing the list of species allowed for import in order to reduce the risk of disease introduction, specifically excluding species known to carry significant disease agents or those that can become established in wild populations.

\section{Declarations}

\section{Acknowledgements}

This study is part of Postdoctoral Research of A.I.P.T who is grateful to CONACYT México (253392) for granting a 1-year scholarship. Sincere and grateful thanks are extended to all at Laboratorio de Patología Acuática CINVESTAVIPN Unidad Merida. Thanks also extended to Andrea Selina Caamal Pool, who helped with field work and Dr. Eduardo Garza Gisholt for donating the ornamental fish.

\section{Author contributions}

The author contributed to the study conception and design. Sampling was performed by Al. Material preparation, data collection and analyses were performed by Al and DH. Technical equipment and support were provided by VM. The first draft of the manuscript was written by Al and RR. DV, commented on previous versions of the manuscript.

\section{Conflict of interest}

The authors have no affiliation with any organization with a direct or indirect financial interest in the subject matter discussed in the manuscript.

\section{Ethical approval}

Page 5/10 
This research was conducted humanely, in line with the "Guidelines for Ethical Treatment of Animals in Applied Animal Behaviour and Welfare Research".

\section{References}

1. Avilés-Quevedo MA, Castelló-Orvay F (2004) Manual para el Cultivo de Jurel. Mexico. INAPESCA. https://www.gob.mx/inapesca/documentos/manual-para-el-cultivo-de-jurel

2. Bondad-Reantaso MG, Ogawa K, Fukudome M, Wakabayashi H (1995) Reproduction and Growth of Neobenedenia girellae (Monogenea: Capsalidae), a Skin Parasite of Cultured Marine Fishes of Japan. Fish Pathology 30:227-231. https://doi.org/10.3147/jsfp.30.227

3. Bush A, Lafferty K, Lotz JM, Shostak AW (1997) Parasitology meets ecology on its own terms: Margolis. Revisited J Parasitol 83:575-583. https://doi.org/10.2307/3284227

4. Bravo-Hollis M (1958) Trematodes de peces marinos de aguas mexicanas. XIV. Cuarto 365 monogéneos de la familia Capsalidae Baird, 1853, de las costas del Pacifíco, incluyendo 366 una especie nueva. Anales Inst Biol Univ Nac Autón México 28:195-216. https://eurekamag.com/research/014/285/014285991.php

5. Bravo-Hollis M, Deloya JC (1973) Catálogo de la colección helmintológica del Instituto de 368 Biologia. Anales Inst Biol Univ Nac Autón México 2:137. http://www.ibiologia.unam.mx/colecciones/helmitos/centro_helm.htm

6. Brazenor AK, Bertozzi T, Miller TL, Whittington ID, Hutson KS (2018a)

7. DNA profiling reveals Neobenedenia girellae as the primary culprit in global fisheries and aquaculture.Mol Phyl Evol129:130137. https://doi.org/10.1016/j.ympev.2018.05.012

8. Brazenor AK, Saunders RJ, Miller TL, Hutson KS (2018b) Morphological variation in the cosmopolitan fish parasite Neobenedenia girellae (Capsalidae: Monogenea). Int J Parasitol 48:125-134. https://doi.org/10.1016/j.jpara.2017.07.009

9. Cedillo PC, Rosales MLM, Constantino CF (2001) Linfoquistosis en peces tetra fantasía (Parambassis baculis) de la ciudad de México. Vet Mex 32:73-76. https://www.redalyc.org/pdf/423/42332111.pdf

10. Conference on Fisheries and Marine Science 441-012058. https://doi.org/10.1088/1755-1315/441/1/012058

11. Contreras MT, Mejía M, Carrillo W (1998) Negative impact on the aquatic ecosystems of the state of Morelos from introduced aquarium and other commercial fish. Aquarium Sci Conserv 2:1-12. https://doi.org/10.1023/A:1009676403693

12. Darriba D, Taboada GL, Doallo R, Posada D (2012) jModelTest 2: More models, new heuristics and parallel computing.Nat Methods9-772. https://www.nature.com/articles/nmeth.2109

13. Gaida HI, Frost P (1991) Intensity of Neobenedenia girellae (Monogenea: Capsalidae) on the Halfmoon, Medialuna californiensis (Perciformes: Kyphosidae), Examined Using a New Method for Detection. Helminthol Soc Wash 129-130. https://doi.org/51849118

14. García-Varela M, Nadler SA (2005) Phylogenetic relationships of Palaeacanthocephala (Acanthocephala) inferred from SSU and LSU rDNA gene sequences. J Parasitol 91:1401-1409. https://doi.org/10.1645/GE-523R.1

15. Gibson D, Harris P, Bray R (2010) Capsalidae Baird, 1853. Accessed through: World Register of Marine Species at http://www.marinespecies.org/aphia.php/aphia.php11-19

16. Hargis WJ (1955) A New Species of Benedenia (Trematoda: Monogenea) from Girella nigricans, the Opaleye. J Parasitol 41:48-50. https://doi.org/10.2307/3273995

17. Hirayama T, Kawano F, Hirazawa N (2009) Effect of Neobenedenia girellae (Monogenea) infection on host amberjack Seriola dumerili (Carangidae). Aquac 288:159-165. https://doi.org/10.1590/S1984-296120180076

18. Hirazaga N, Ishizuka R, Hagiwara H (2016a) The effects of Neobenedenia girellae (Monogenea) infection on host amberjack Seriola dumerili (Carangidae): Hematological and histopathological analyses. Aquac 461:32-39. https://doi.org/10.1016/j.aquaculture.2016.04.007

19. Hirazaga N, Tsubone S, Takano R (2016b) Anthelmintic effects of 75ppm hydrogen peroxide treatment on the monogeneans Benedenia seriolae, Neobenedenia girellae, and Zeuxapta japonica infecting the skin and gills of greater amberjack Seriola dumerili. Aquac 450:244-249. https://doi.org/10.1016/j.aquaculture.2015.07.028 
20. Hutson KS (2007) Parasite interactions between wild and farmed yellowtail kingfish (Seriola lalandi) in southern Australia. Thesis (Doctor of Philosophy). South Australia. The University of Adelaide. 194p

21. Magalhães-Cardoso PH, Carvalho-Balian S, Sousa-Soares H, Tancredo KR, Laterça-Martins M (2019) Neobenedenia melleni (Monogenea: Capsalidae) in ornamental reef fish imported to Brazil. Rev Bras Parasitol 28:1-6.

https://doi.org/10.1590/s1984-296120180076

22. Mendoza R, Luna S, Aguilera C (2015) Risk assessment of the ornamental fish trade in Mexico: analysis of freshwater species and effectiveness of the FISK (Fish Invasiveness Screening Kit). Biol Invasions 17:3491-3502. https://doi.org/0.1007/s10530-015-0973-5

23. Moser M, Haldorson L (1982) Parasites of two species of surfperch (Embiotocidae) from seven Pacific coast locales. J Parasitol 68:733-735. https://doi.org/10.2307/3280937

24. Nam U, Hyun-Joon S, Hwang I, Jeong-Ho K (2020) Neobenedenia girellae infection of aquarium-raised snubnose pompano (Trachinotus blochii) in Korea. Fish Pathol 33:015-021. https://doi.org/10.7847/jfp.2020.33.1.015

25. Nadler SA, Hudspeth DSS (1998) Ribosomal DNA and phylogeny of the Ascaridoidea (Nemata: Secernentea): Implications for morphological evolution and classification. Mol Phyl Evol 10:221-236. https://doi.org/10.1006/mpev.1998.0514

26. Ogawa K, Bondad-Reantaso MG, Fukudome M, Wakabayashi H (1995) Neobenedenia girellae (Hargis, 1955) Yamaguti, 1963 (Monogenea: Capsalidae) from cultured marine fishes of Japan. J Parasitol 81:223-227. https://doi.org/10.2307/3283923

27. Ogawa K, Miyamoto J, Wang HC, Lo CF, Kou GH (2006) Neobenedenia girellae (Monogenea) infection of cultured cobia Rachycentron canadumin Taiwan. Fish Pathol 33:303-309. https://doi.org/10.3147/jsfp.41.51

28. Ohno Y, Kawano F, Hirazawa N (2009) The effect of oral antibiotic treatment and freshwater bath treatment on susceptibility to Neobenedenia girellae (Monogenea) infection of amberjack (Seriola dumerili) and yellowtail (S. quinqueradiata) hosts. Aquac 292:248-251. https://doi.org/10.1016/j.aquaculture.2009.04.012

29. Putri RDB, Rivaie AR, Subekti S, Sari PDW (2020) Neobenedenia girellae infestation on cobia (Rachycentron canadum) in Hurun Bay Lampung, Indonesia. 2nd International

30. Rambaut A (2000) 'Estimating the Rate of Molecular Evolution: Incorporating Non-Contemporaneous Sequences into Maximum Likelihood Phylogenies'. Bioinformatics 16:395-399. https://doi.org/10.1093/bioinformatics/16.4.395

31. Salgado MG, Rubio GM (2014) Helmintos parásitos de peces de agua dulce introducidos, en R. Mendoza y P. Koleff (coords.), Especies acuáticas invasoras en México. Comisión Nacional para el Conocimiento y Uso de la Biodiversidad, Ciudad de México, México, p. 269-285. https://www.researchgate.net/publication/259821562

32. Seng LT (1997) Control of parasites in cultured marine finfishes in Southeast Asia-an Overview. Int J Parasitol 27:1177-1184. https://doi.org/10.1016/S0020-7519(97)00115-X

33. Sepúlveda FA, González MT (2019) DNA barcoding evidence for the first recorded transmission of Neobenedenia sp. from wild fish species to Seriola lalandi cultured in an open recirculating system on the Coast of Northern Chile. Aquac 501:239-246. https://doi.org/10.1016/J.AQUACULTURE.2018.11.037

34. Sicuro B, Luzzana U (2016) The state of Seriola spp. other than yellowtail (S. quinqueradiata) farming in the world. Reviews in Rev Fish Sci 24:314-325. https://doi.org/10.1080/23308249.2016.1187583

35. Shinn A, Pratoomyot J, Bron J, Paladini G, Brooker E, Brooker A (2015) Economic impacts of aquatic parasites on global finfish production.Global aquaculture advocate1-7.

https://www.researchgate.net/publication/283506528_Economic_impacts_of_aquatic_parasites_on_global_finfish_production

36. Stamatakis A (2006) RAxML-VI-HPC: Maximum likelihoodbased phylogenetic analyses with thousands of taxa and mixed models. Bioinformatics 22:2688-2690. https://doi.org/10.1093/bioinformatics/btl446

37. Stock SP, Campbell JF, Nadler SA (2001) Phylogeny of Steinerma Travassos, 1927 (Cephalobina: Steinermatidae) inferred from ribosomal DNA sequences and morphological characters. J Parasitol 87:877-899. https://doi.org/10.1645/00223395(2001)087[0877:POSTCS]2.0.C0;2

38. Tamura K, Stecher G, Peterson D, Filipski A, Kumar S (2013) MEGA6: Molecular Evolutionary Genetics Analysis version 6.0. Mol Phyl Evol 30:2725-2729. https://doi.org/10.1093/molbev/mst197

39. Tedesco P, Caffara M, Moreira NMR, Gomes C, Gustinelli A, Fioravanti ML (2021)

Page $7 / 10$ 
40. Occurrence of Neobenedenia girellae (Monogenea: Capsalidae) in Gilthead Seabream Sparus aurata (Actinopterygii: Sparidae) Cultured in Portugal. Pathogens 10-1269. https://doi.org/10.3390/pathogens10101269

41. Thompson JD, Higgins HG, Gibson TJ (1994) CLUSTALW: improving the sensitivity of progressive multiple sequence alignment through sequence weighting, position specific gap penalties and weight matrix choice. Nucleic Acids Res 22:46734680. https://doi.org/10.1093/nar/22.22.4673

42. Whittington I, Kearn GC (1993) A new species of skin parasitic Benedeniine monogenean with a preference for the pelvic fins of its host, Lutjanus carponotatus (Perciformes: Lutjanidae) from the Great Barrier Reef. J Nat Hist 27:1-14. https://doi.org/10.1080/00222939300770011

43. Whittington ID, Horton MA (1996) A revision of NeobenedeniaYamaguti,1963 (Monogenea: Capsalidae) including a redescription of $N$. melleni (MacCallum, 1927) Yamaguti, 1963. J Nat Hist 30:1113-1156.

https://doi.org/10.1080/00222939600770611

44. Whittington ID (2004) The Capsalidae (Monogenea: Monopisthocotylea): a review of diversity, classification and phylogeny with a note about species complexes. Folia Parasitol 51:109-122. https://doi.org/10.14411/fp.2004.016

45. Whittington RJ, Chong R (2007) Global trade in ornamental fish from an Australian perspective: the case for revised import risk analysis and management strategies. Prev Vet Med 81:92-116. https://doi.org/10.1016/j.prevetmed.2007.04.007

\section{Tables}

Due to technical limitations, tables 1 and 2 are only available as a download in the Supplemental Files section.

\section{Figures}
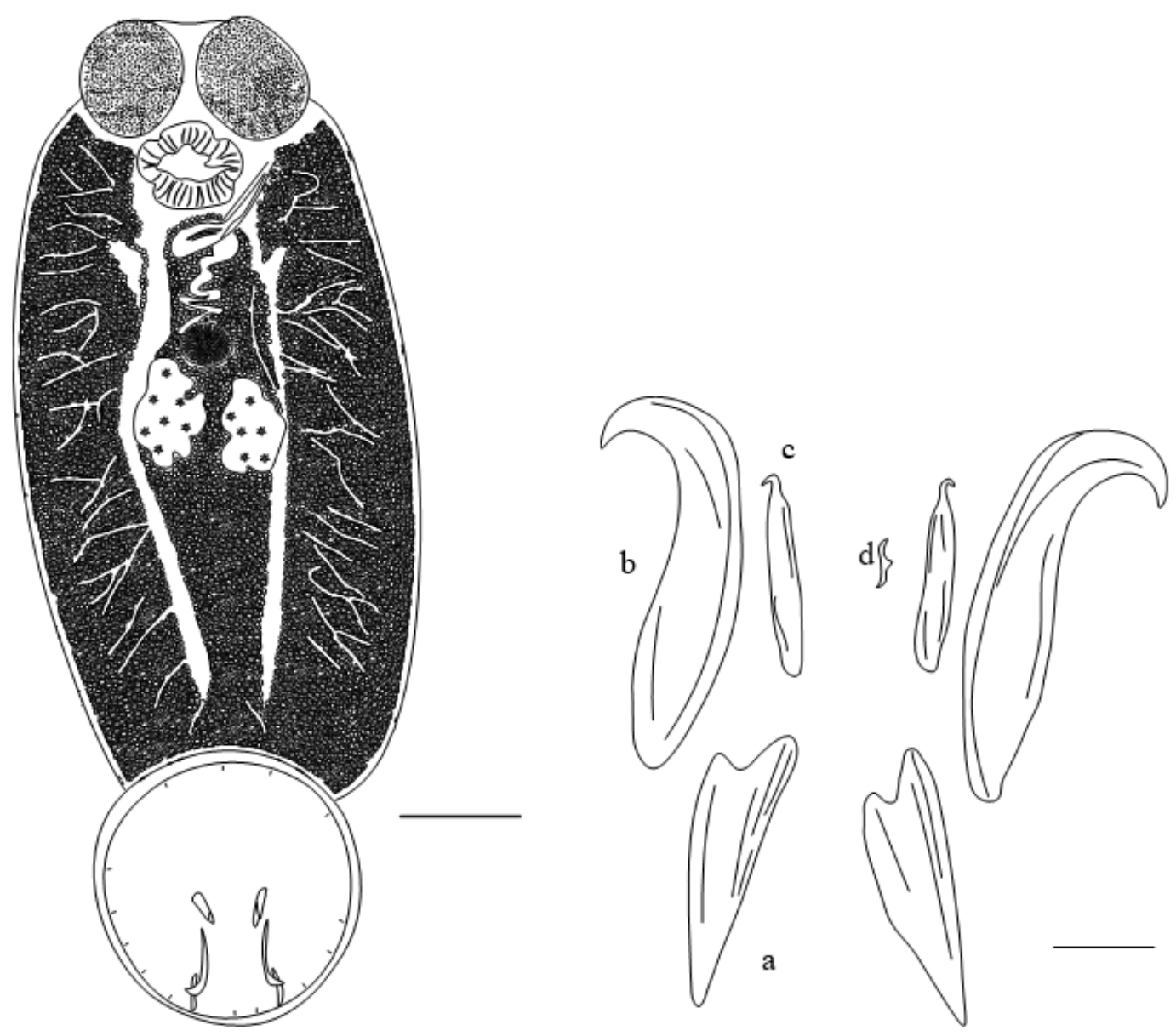


\section{Figure 1}

Neobenedenia girellae (Hargis, 1955) Yamaguti, 1963 from marine ornamental fish. Ventral view. (a) accessory sclerite; (b) anterior hamulus; (c) posterior hamuli; (d) marginal hooks.

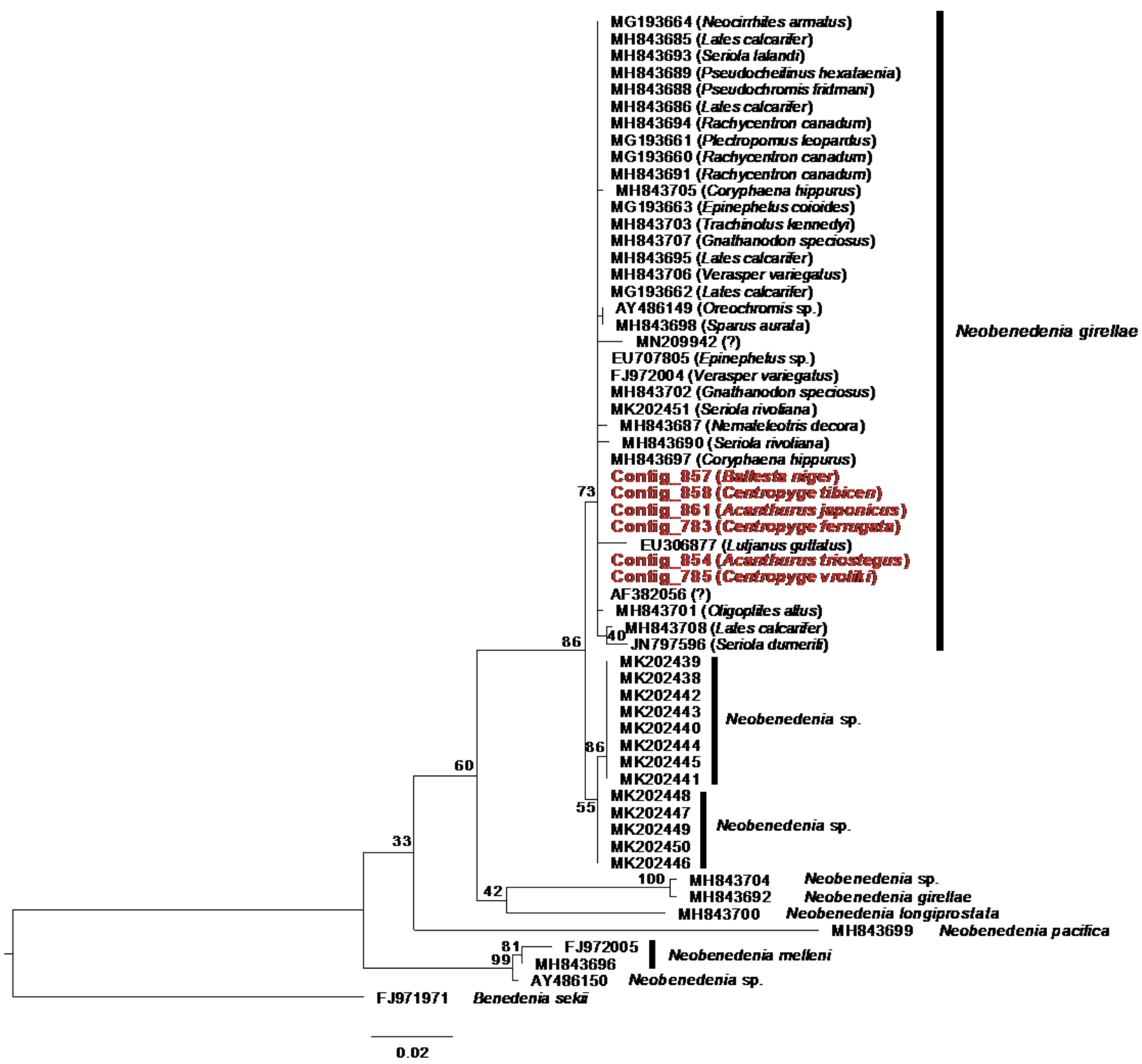

Figure 2

Phylogenetic relationships of Neobenedenia species, found in several host species resulting from the Maximum Likelihood analysis with the 28S rDNA gene. The newly generated sequences are highlighted in red. Numbers near the tree nodes represent the Bootstrap support values and the scale-bar indicates the number of substitutions per site.

\section{Supplementary Files}

This is a list of supplementary files associated with this preprint. Click to download. 
- Table2.xIsx

Page 10/10 